\title{
アジア太平洋戦争期のインド研究 佐保田鶴治のインド社会論によせて—
}

\section{藤 井毅}

\section{1 はじめに：問題の設定}

インド哲学者の佐保田鶴治が，昭和 19 年 4 月 28 日付の「インパール陥落を目 前にして」との刊記を伴った著書『印度の社会に就いて』を『大東亜学術叢誌』 の第二巻目として大阪・秋田書店より公刊したのは, 1944（昭和 19）年 12 月のこ とである。本書は，第一編「印度於けるカストの問題」と第二編「現代に於ける カストの趨勢」の二章によって構成されており, 序文によると1943（昭和 18）年 の夏と秋に大東亜学術協会の主催で京都と大阪において二度に亘り開催された講 演会の報告を䌕めたものであることが同い知れる ${ }^{1}$.

佐保田が, 本書に於いて目指したのは，「カストの実相を誤りなく江湖に知って 貪い度いといふことと, カストの将来に就ての見透しと, その指導を確立したい といふこと」(同書, 2 頁:以下, 頁数のみを略記) であり, 二つの章は, それぞれそ の目的に対応する内容を持っていた，同時に雨編は，「印度を理解するには欧米的 観方に掴へられないことが肝要で・・・所謂「からごころ」を清くはらひすてて, まことの「やまとごころ」に返って見てゆくことが必要で」あり，「吾々日本人は 大東亜同胞の長兄たらんとする抱負を抱く以上，弟達の事情を知悉していなけれ ばならない，又扶育，掖導の方針を確立していなければならない．若し此の點に 於て欠けているとすれば, 長兄たる資格が無い」(2 頁) とする観点に立脚してい た，彼のこうした論調は，カーストの将来を論じた第二編において，全面的かつ 縦横に展開されていた。

ウパニシャッドを始めとするインド古代哲学を專門とする佐保田の著述として は, この本は明らかに異質であるばかりか, 刊行時期ともども,「時局」の影響が 極めて色濃く見て取れる論述形態においても, 彼の一連の著作のなかでは際立っ た存在であると言えよう。そのためか, 戦後, 戦前と戦中に刊行されたインド思 想に関わる彼の著作が再刊され, 同分野の著作が陸続と公表されていったのに比 
ベると，この本は，忘れ去られ，いわば埋もれた存在となっていったのである.

本稿では, まずもって, 本書に於いて展開された佐保田のカースト論が, 単に 同時代の研究状況のみならず，戦後に展開されたインド社会研究に照らしても突 出した内容を持っていることを示し，その上で、それを本邦に於けるインド研究 史のなかで正当に位置付け，その再評価に連なる前提を用意したい. 彼が提示し た論点の幾つかは，今日においても猶その意味を失っていないばかりか, 戦後の インド研究が 1970 年後半に入ってょうやく獲得した観点を先取りしていた点でも 論究に值すると考えるからである。しかしながら，佐保田のインド社会観に検討 を加える作業は，本書が，何故，忘却の淵に追いやられたのかという問い掛けと ともに, 彼が立脚した思想そのものに対する検討を抜きにしては成り立ちえない. そして, それは, 考究の視座を単にインド思想・哲学研究史にとどまらず, 日本 を含むアジア近現代史へと不可避に広げてゆくことを求めるのである ${ }^{21}$.

\section{2 第一編「印度におけるカストの問題」をめぐって}

佐保田は，まずもってカーストが, 他称であることを確認し, ヴァルナvarna と シャーティ $j \bar{a} t i(シ ゙ ャ ー ト ~ j a \bar{t})$ を区別した上で, 両者がカーストと必ずしも一致し ないことを指摘する. わけても四ヴァルナとカーストの混同を批判する (18,28 頁). その上で, 彼はカースト制度の成立要素として三点を挙げ [11人種的因素(2)職業 的因素(3)宗教的因素 (50-51 頁) ]，三期よりなるカースト制度の形成史を想定する [1)前スートラ期（カスト制度の萌芽期）(2)スートラ期（カスト制度の確立期. マヌ法 典を典型とするが，その記述をもって直ちに真なるものとしてはならず，ましてやこの文 献よりカスト制度が始まったわけではない) (3)民族的復興期（イスラーム諸勢力の侵入 によりヒンドゥーは内的・防御的復古を遂げ, 民族的復古運動に乗じて印度教が, 反カス トの立場をとる宗教に反発し，カストを復興させ発展させた）（40,43,49頁を要約）]．ここ で強調されるのは, カーストの歴史的形成と変容という観点である. 佐保田の立 論には, 現在ではそのまま首肯出来無い点が含まれてはいるものの, サンスクリッ 卜語文献に依拠したカースト解釈が横溢していた同時代においては突出した見方 であり，その先駆性が際立っていた。

佐保田のカースト論は, 次の一文に見られるような問題意識に立脚していた。

「カストを成立せしめた諸因素の各々の問題と，その因素が歷史的に如何に相作用した かという沿革の問題と,この両面から見なければカストの本質は明らかにならぬ」(30 頁). 「「カスト」に関する根本の問題は「カスト」は印度のヒンドゥ（Hindu）即ち印度教徒の 
社会にとって本質的なものであるかどうか？という点にありませう.・・・この問題はや がて，印度は独立する能力ありや？又資格ありやといふ問題にも関連して来ますから, どうしても政治問題に絡んで参ります。・・・カストは印度人の民族精神とか国民精神と か云はるべきものの全部又は一部であるかどうか？」(1-2 頁).

佐保田はこの問題設定に対して,

「一つの民族又は国家が強力に存続してゆく為には民族精神又は国民精神が無ければな りません. 印度に古来釈迦やマハービーラの如き偉大な宗教家が数々出たけれども, 終に は印度数の中へ吸収されて了ったといふことは，婆羅門的伝統が印度の民族精神である」 （52 頁）と見なしていたものの，

「カスト制度と印度教は相依的関係にあるが因果的関係にあるのではない. 印度教はカ スト制度と離れて存在し得ると考へられます. 印度教は亡ぼさなくしてもカストは無くす ことが出来ると考へるのであります．印度教は印度人にとっての魂であるから之れを亡ぼ したり完全に改造するなどといふことは到底不可能であり, それは印度人其の者の改変又 は滅亡を意味するのであります。然しカスト制度は色々な事情から発成したのだから, 其 れ等の事情さへ無くなるか, 変化すれば, 従ってカストも改造したり, 無くしたりする事 は出来ないことは無い. 又カスト制度は印度教と結びついて発達したものだから印度教が 印度人の心を掴んで居る限りカスト制度も亡びない. 又亡ぼすべきではない.ただその弊 を除去すべきである」（51-52 頁）と考えていたのだった.

こうした指摘は，同時代の西欧の学界における議論と明確に対応しており，ま た，それは，差別と排除を招来する「カースト意識 caste spirit」を非宗教的な社会 制度を意味する「カースト区分 caste distinction」と分かつことで, 利用論的にカー ストを捉えようとしたキリスト教宣教師達のカースト観にも連なるものであった ${ }^{3)}$.

\section{3 第二編「現代に於けるカスト」をめぐって}

カーストの変容ということを繰り返し強調するのが本書の特徵であるが, わけ ても本編においてそれが全面的に展開されてゆく.

「この制度と雖も亦他の諸種の社会形態と同様に時の流れの中で不断に歴史的変遷を遂 げつつあるといふことであります. 是がカスト制度そのものの形態だといって示すべきも のは, 事実の上には存しない筈であります. 従って吾等がカスト制度は斯く斯くのもので あると云って説明しますのは, カスト制度を其の変遷の中から取り出して之を謂わば図式 化した結果に外ならぬのであります. 然からば図式の如き完全なカスト制度に最も近い発 達を遂げた時代は何時頃かと云へば，それは回教徒政権の支配時代の末期から英人支配の 前半の時期に相當すると云ってよいでありませう」(58 頁). 
かくして，植民地支配の確立と共にカースト制度には，一面崩壊，一面強化と いう趨勢が生じ始めたのだが (60 頁), その要因は, 崩壊については, 植民地政府 の政策・司法・立法・教育・工業化・都市化・社会宗教改革運動・キリス卜教／ イスラーム教の影響, 強化については, 分離選挙・留保措置・国勢調査・カース ト単位の福利厚生事業・カースト組織の結成，のように整理される $(61 〜 68$ 頁を 要約)。佐保田の分析視角は，多岐に亘り細部に及んでいた。それは，同時代の カースト研究が未だ包摂し得なかった不可触民と不可触制にも向いていたのであ る.

では，こうして変化を遂げてきたカーストが，同時代のインドに於いてどのよ うに存在していたのであろうか，佐保田は，次のように述べる。

「旧来職業の制限や宗教的感情に基づいていた所のカスト的秩序といふものは一掃され てしまったが, 従来のカスト的分域に基づく団結はいよいよ強固になってきたのでありま す。・・カストは崩壊しつつあるのでは無い，只だ変態しつつあるのだと申したが，そ れはカスト制度を隔離と秩序の二契機に分かって考へる場合には，秩序の方は崩壊した が，隔離の方はある意味に於て強化されたという点を強調しようが為でありました．印度 における政治, 経済其の他一般社会生活の変革が直ちに印度のカスト的分裂を匡正して印 度社会の平等的統一を実現するといふ如き楽観は禁物である事を理解して頂き度いのであ ります。. ․カスス的団結は一層強固となり, 感情的にはカスト的愛国心とも云うべき 排他的偏狭なる共同感情が生まれ，カスト間には階級的観念に基く不断の闘争が起り，統 一的民族意識は一層晦まされるに至ったのであります」(73 頁)

「印度教的社会に特有なる組織としてのカスト制度の本質的要素をなすものは宗教的動 機であり, 次に職業世襲制でありますが, 今日のヒンドゥ社会に於いては己にこの両要素 といふものが殆ど滅亡に瀕しているのでありますから, 最早こんにちはカストとよばれる べき特色ある階級制度は存在していないのだと申しても可いのであります」(75 頁)

将来におけるカーストの変遷動向は, 「四つの相」(過去, 現在, 二つの選択肢を持 つ将来）によって規定されるという（82 頁以下），前二者は，既に述べたことの繰 り返しだが,「将来に於けるカスト相」では, インドの政治的将来と対応した二つ の選択肢のもとで独自の立論が展開されていた．

第一の選択肢「自治領としてのインドにおけるカストの相」

「カスト的組合の大きさといふものには多少の変化は起りませう. 然しカスト的分裂, カスト至上主義は依然として存続するものと想像されるのであります. 勿論漸次に経済的 階級の色彩を濃厚にはして参りませう. 然し階級的分離又は分裂を解消した社会的平等を なさないのは勿論, 印度の民族意識の統一といふことからはいよいよ遠ざかるのでは無い 
かと思ふのであります。・・・単に一自治領としての印度に於ては, カスト問題はただ社 会の平等とか, 機会の均等とかいふ方面のみから取り上げられるだけでありませう。・・・ 自治領といふような他律的な政體を目標としたのでは, 到底カスト的感情を打破するほど の民族意識を発揚することはできないのであります.カスト至上主義の完全打破には更に 高い段階を目標に致さねばなりません. 即ち印度民族の完全独立といふ段階に至ってカス トは初めて真にその到達すべき相を探ることができる」(88-89 頁)

第二の選択肢「完全独立後のインドにおけるカストの相」

「カストは印度の完全独立の日に於ても何等かの形に於て必ず残るといふことであります. 数百年乃至数千年の間血族団体といふ意味を以て印度人の生活を支配し来ったカストに対 する感情が一朝にして印度人の心から去るといふことは到底あり得ないと見なければなり ません.・・・(カストは) 然し形骸にもせよ何故に残っているのであるか？それはカス トの有する血族意識であります。事実上カストは必ずしも血族団体ではありません，然し 血族的意義をもっている. 即ちカストの成員の間に, 同一の先祖から出た後裔であるとい ふ伝統的信仰若くは感情があって, その団結の紐帯をなしていることは確かであります. この血族的親和感は容易に亡びるもので無い. 少なくとも東洋民族に於ては根強く維持さ れて来たのであります。我が国で「家」といひ，支那で「宗族」といひ，印度において 「カスト」と言っているものはいずれも同一形式の共同体であります。かういろものは如 何に西洋文明が流行しても, 東洋民族が其の固有の文化を完全に失って附属的民族に化し 去らぬ限り，地を払って消え去るものではありません」(92-93 頁)

「斯かる血統的な関連を完全に打破し, 絶対個人主義的なイデオロギーに立たなければ強 力なる近代国家を建てることはできないものであるのか？・・・血族的共同感情といふ ものと民族意識といふものは絶対両立し得ないものであろうか？と申しますと，吾々は 誇らかに否！と答えることが出来ます，何となれば吾々は吾等の日本を以て実証したか らであります。吾々は全力を挙げて個人主義的西洋文明を輸入し, 短時日の間に強大な近 代国家を建設しました．然し吾等は決して完全な個人主義者にはならなかった．否なり得 なかったのであります」(95 頁)

ここにおいて，第一編において自ら提示した利用論を含む問い掛けに対する回 答が完結し，佐保田のカースト論の全容が立ち現れてくる. カーストが脱宗教化 し，政治経済上の権益の受け皿へと変容したと論じ，さらにはカーストの同族意 識が, 虚構の血統意識に基づいていることの指摘はきわめて鋭く，今日のカース 卜研究においても十分に通用するものである。そこにいたる立論過程では，19世 紀以降展開された社会宗教改革運動のみならず, 同時代の研究動向が的確に把握 されていた。ただし，それがどのような文脈で展開されていたのかというと，明 
らかに「近代の超克」論に直結する立場であった。その叙述内容からは，個人的 かつ契約的社会構成を共同体的社会構成によって置換しょうとするドイツ法社会 論の思想的影響すら見て取れるのである ${ }^{4)}$. この立場は, 彼のカーストの変容とそ の機能に関する精緻かつ鋭利な分析と切り離して論じることが出来ないほど有機 的に結びついていたのだった，そうであるがゆえに，佐保田にしてみれば，そこ よりカースト論のみを抽出して提示することは能わなかったのであろう。戦後に 於ける本書の忘却は，こうして用意されていったのである.

\section{4 まとめにかえて}

本書では，同時代に於いて翻訳で紹介されていたブーグレやセナールらのカー スト論が批判されていた。 しかしながら, それは極めて理知的なものであり, 故 無き排斥ではなかった，その意味でも，本書は，時代の産物ではあったが，単な る無思想な時局便乗型の著述ではなかったのである。それ故に佐保田のカースト 論を最終的に評価するためには，全てを彼個人の問題に還元してしまうのではな く, 当時の京都学派の, わけても「近代の超克論」や「世界史の哲学」の思想系 譜のなかで位置付けて検討を加える必要が出てこょう.それは, 今後の課題である.

インド哲学者にしてヨーガの実践者として戦後を生きた佐保田の精神史につい ては，多大の関心が掻き立てられるものの，その個人史を熟知しないがゆえに， そこには安易に立ち入るべきではなかろう。同門・同学の人々による今後の取り 組みに期待したい.

1）本書が含まれる叢誌第一巻は, 同一の主催団体による講演会記録である [日比野文夫, 水野清一『蒙疆に於ける最近の考古学的発見』(大阪 ·大和書院, 1943 年 7 月) ]. 佐保田 は, 一貫してカストという表記を用いている. 関連先行研究として, 田中雅一「大東亜共 栄圈のインド: 戦中の邦語文献におけるカーストと民衆ヒンドゥー教」中生勝美編『植民 地人類学の展望』(風響社， 2000 年)，45〜 69 頁を参照のこと. 2) cf. 藤井毅「イン ド，中国，そして日本」『東方』第 241 号 (2001 年 3 月), $2 \sim 5$ 頁. 3 ） cf. 藤井毅「イ ギリスの植民地支配とカースト」『岩波講座世界歷史第 20 巻（アジアの〈近代〉）』(岩波 書店，1999 年）２21-243 頁４４） cf. 酒井哲哉「「国際関係」の成立」『創文』第 431 号 (2001 年 5 月), $6 \sim 10$ 頁.

〈キーワード〉 カースト論, 佐保田鶴治, インド社会論 